\title{
Ceria co-doped with calcium (Ca) and strontium (Sr): a potential candidate as a solid electrolyte for intermediate temperature solid oxide fuel cells
}

\author{
Nandini Jaiswal • Devendra Kumar • Shail Upadhyay • \\ Om Parkash
}

Received: 22 March 2013 /Revised: 5 June 2013 / Accepted: 6 June 2013 / Published online: 11 July 2013

(C) The Author(s) 2013. This article is published with open access at Springerlink.com

\begin{abstract}
Co-doped samples of $\mathrm{Ce}_{0.95-x} \mathrm{Ca}_{0.05} \mathrm{Sr}_{x} \mathrm{O}_{1.95-x}$, where $(x=0.00,0.01,0.02$, and 0.03$)$, have been prepared by auto-combustion method and characterized to explore their use as a solid electrolyte for intermediate temperature solid oxide fuel cells (IT-SOFCs). Crystal structure, microstructure, and ionic conductivity have been characterized by $\mathrm{X}$-ray diffraction, scanning electron microscopy, and impedance spectroscopy, respectively. All the compositions have been found to be single phase. Results show that the samples co-doped with $\mathrm{Ca}$ and $\mathrm{Sr}$ exhibit higher ionic conductivity than the samples singly doped with $\mathrm{Ca}$ in the intermediate temperature range. $\mathrm{Ce}_{0.93} \mathrm{Ca}_{0.05} \mathrm{Sr}_{0.02} \mathrm{O}_{2-\delta}$ exhibits maximum conductivity among all the compositions. This may be a potential candidate as a solid electrolyte for IT-SOFCs.
\end{abstract}

Keywords Doped ceria electrolyte $\cdot$ Co-doping effect $\cdot$ Ionic conductivity $\cdot$ Solid oxide fuel cells

\section{Introduction}

Oxide ion conductors are used in oxygen sensors [1-3] and solid oxide fuel cells (SOFCs) [4-6]. Among these applications, SOFCs are especially developed as a clean and efficient power source for generating electricity from a variety of fuels. For the commercial application of the SOFCs for the

N. Jaiswal $\cdot$ D. Kumar $\cdot$ O. Parkash $(\bowtie)$

Department of Ceramic Engineering, Indian Institute of

Technology, Banaras Hindu University, Varanasi 221005, India

e-mail: oprakash.cer@itbhu.ac.in

S. Upadhyay · O. Parkash

Department of Applied Physics, Indian Institute of Technology,

Banaras Hindu University, Varanasi 221005, India distributed heat-power co-generation, an operation temperature in the range $500-700{ }^{\circ} \mathrm{C}$ is highly desirable. This is in view of the cost effectiveness because inexpensive stainless steel may be used for this purpose.

Doped ceria electrolytes have attracted great interest in recent years because of their potential as a solid electrolyte for intermediate temperature solid oxide fuel cells (IT-SOFCs) application [7]. In $\mathrm{CeO}_{2}$, temperature facilitates movement of oxygen ions through oxygen vacancies which are produced in the oxygen sublattice to neutralize the deficiency of charge created by lower valent dopant cations. Doped ceria oxides show much higher ionic conductivity at relatively low temperatures $\left(500-700{ }^{\circ} \mathrm{C}\right)$ as compared with yttria-stabilized zirconia. These have been extensively studied as the most promising electrolyte materials for IT-SOFCs. Among the various ceria compositions investigated so far [8-19], Gdand Sm-doped ceria (GDC and SDC) are considered as the most suitable low-temperature solid electrolytes for IT-SOFCs application. Both $\mathrm{Gd}_{2} \mathrm{O}_{3}$ and $\mathrm{Sm}_{2} \mathrm{O}_{3}$, however, are very costly. Therefore, there is an increasing interest to develop new cost-effective ceria-based electrolytes.

Ceria doped with alkaline earth oxides such as $\mathrm{CaO}[20,21]$ and $\mathrm{SrO}[22,23]$ has been studied extensively. Electrical conductivity of $\mathrm{CaO}$ - and $\mathrm{SrO}$-doped ceria is much higher than that of undoped ceria. The highest conductivity was found in the composition $\mathrm{Ce}_{0.90} \mathrm{Ca}_{0.10} \mathrm{O}_{1.90}$ by Shing et al. [24] which is $\sim 10^{-3} \mathrm{~S} \mathrm{~cm}^{-1}$ at $600{ }^{\circ} \mathrm{C}$. Yamashita et al. [25] found that the composition $\mathrm{Ce}_{0.90} \mathrm{Ca}_{0.10} \mathrm{O}_{1.90}$ has the highest conductivity which is $\sim 10^{-2} \mathrm{~S} \mathrm{~cm}^{-1}$ at $600{ }^{\circ} \mathrm{C}$. Banerjee et al. [26] studied the electrical properties of $\mathrm{Ce}_{1-x} \mathrm{Ca}_{x} \mathrm{O}_{2-\delta}(0.05 \leq x \leq 0.20)$ samples prepared by a mixed fuel process followed by sintering at $1,250{ }^{\circ} \mathrm{C}$. They found that the composition $\mathrm{Ce}_{0.80} \mathrm{Ca}_{0.20} \mathrm{O}_{1.80}$ exhibits the highest conductivity $\left(1.29 \times 10^{-2} \mathrm{~S} \mathrm{~cm}^{-1}\right)$ at $600^{\circ} \mathrm{C}$. Compositions $\mathrm{Ce}_{1-x} \mathrm{Ca}_{x} \mathrm{O}_{2-\delta}$ with $0.05 \leq x \leq 0.20$ have been prepared by auto-combustion method and characterized. 
$\mathrm{Ce}_{0.95} \mathrm{Ca}_{0.05} \mathrm{O}_{1.95}$ exhibits the maximum conductivity in this system. Composition exhibiting maximum conductivity in this system has been reported to be different by different authors. This may be due to minor changes in the purity of raw materials and mainly changes in the processing conditions.

Co-doping of ceria has been found to be very effective for enhancement of conductivity in recent years [27-37]. Most of these compounds contain rare earth elements as a constituent. In the present investigations, effect of co-doping has been studied using $\mathrm{Sr}$ as a co-dopant in the composition $\mathrm{Ce}_{0.95} \mathrm{Ca}_{0.05} \mathrm{O}_{1.95}$, which exhibits the maximum conductivity in our investigation as mentioned above.

Co-doping with $\mathrm{Sr}$ in some rare earth singly doped ceria has been reported to enhance their conductivity [38-41]. In order to explore cheaper solid electrolyte for ITSOFCs, a few samples of ceria co-doped with $\mathrm{Ca}$ and $\mathrm{Sr}$, viz.
Fig. 1 Powder X-ray diffraction patterns of various compositions. a CCO5. b CC5S1. c CC5S2. d CC5S3 sintered at $1,350{ }^{\circ} \mathrm{C}$

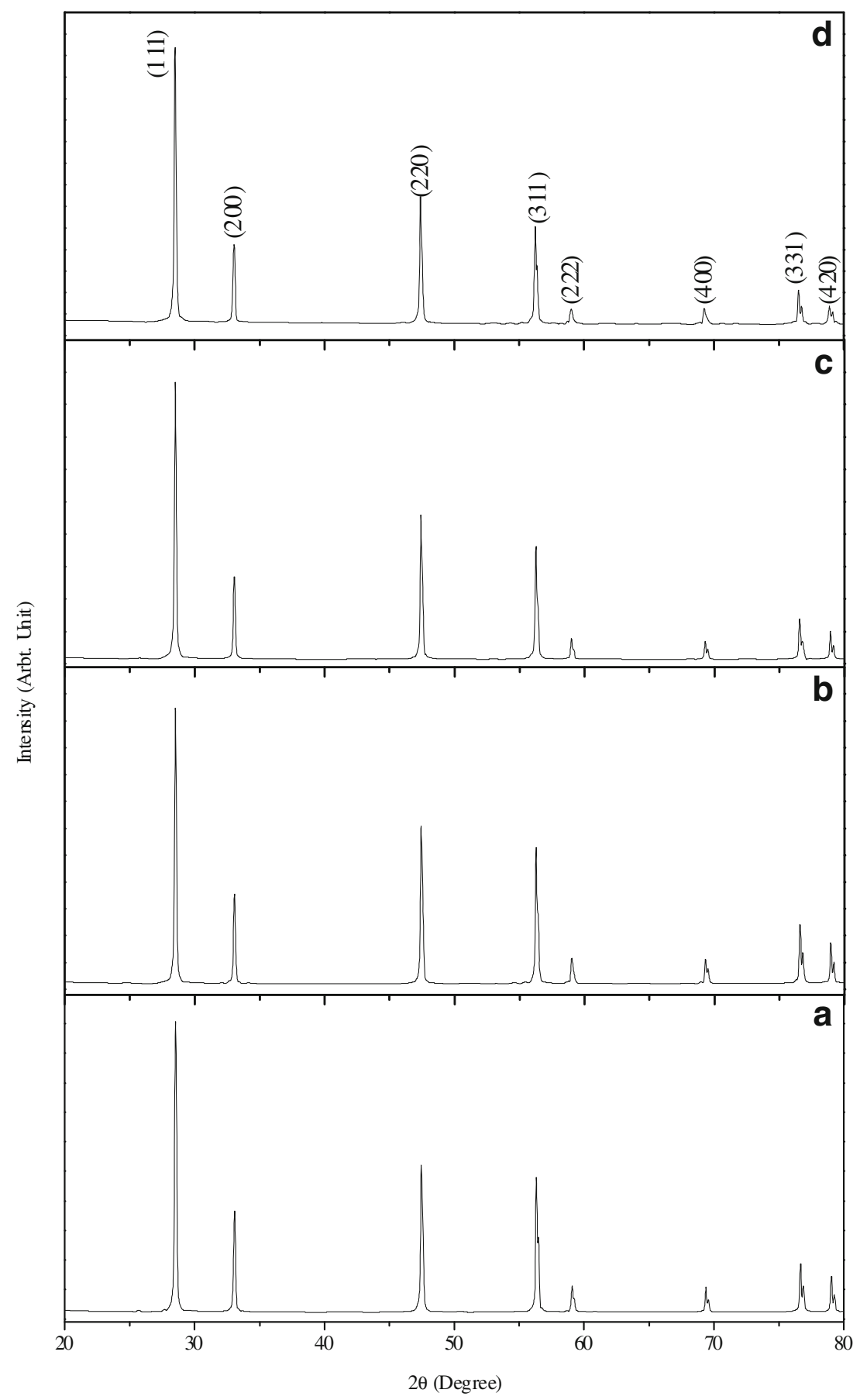


Table 1 Crystallite size, lattice parameter, and percent theoretical density of compositions in the system $\mathrm{Ce}_{0.95-x} \mathrm{Ca}_{0.05} \mathrm{Sr}_{x} \mathrm{O}_{1.95-x}$

\begin{tabular}{llllll}
\hline S. no. & Compositions & $\begin{array}{l}\text { Crystallite size of } \\
\text { sintered powder }(\mathrm{nm})\end{array}$ & Lattice parameter $(\AA)$ & $\begin{array}{l}\text { Experimental } \\
\text { density }(\mathrm{g} / \mathrm{cc})\end{array}$ & $\begin{array}{l}\text { Percent of theoretical } \\
\text { density }\end{array}$ \\
\hline 1. & $\mathrm{Ce}_{0.95} \mathrm{Ca}_{0.05} \mathrm{O}_{1.95}$ & 56 & $5.4120 \pm 0.0003$ & $6.60 \pm 0.02$ & 97.0 \\
2. & $\mathrm{Ce}_{0.94} \mathrm{Ca}_{0.05} \mathrm{Sr}_{0.01} \mathrm{O}_{1.94}$ & 47 & $5.4174 \pm 0.0002$ & $6.69 \pm 0.02$ & 98.3 \\
3. & $\mathrm{Ce}_{0.93} \mathrm{Ca}_{0.05} \mathrm{Sr}_{0.02} \mathrm{O}_{1.93}$ & 57 & $5.4192 \pm 0.0002$ & $6.70 \pm 0.03$ & 98.5 \\
4. & $\mathrm{Ce}_{0.92} \mathrm{Ca}_{0.05} \mathrm{Sr}_{0.03} \mathrm{O}_{1.92}$ & 55 & $5.4201 \pm 0.0006$ & $6.62 \pm 0.03$ & 97.5 \\
\hline
\end{tabular}

$\mathrm{Ce}_{0.95} \mathrm{Ca}_{0.05} \mathrm{O}_{1.95}(\mathrm{CCO} 5), \mathrm{Ce}_{0.94} \mathrm{Ca}_{0.05} \mathrm{Sr}_{0.01} \mathrm{O}_{1.94}$ (CC5S1), $\mathrm{Ce}_{0.93} \mathrm{Ca}_{0.05} \mathrm{Sr}_{0.02} \mathrm{O}_{1.93}$ (CC5S2), and $\mathrm{Ce}_{0.92} \mathrm{Ca}_{0.05} \mathrm{Sr}_{0.03} \mathrm{O}_{1.92}$ (CC5S3), have been synthesized by citrate-nitrate route and characterized. Our results show that there is an enhancement in ionic conductivity by co-doping.

\section{Experimental}

Sample preparation

Starting chemicals used for the synthesis were ceric ammonium nitrate $\left(\mathrm{NH}_{4}\right)_{2}\left[\mathrm{Ce}\left(\mathrm{NO}_{3}\right)_{6}\right]$, (Qualikems, India; $99.00 \%$ ), calcium carbonate (Reidel, India; $>99.5 \%$ purity), strontium nitrate (Reidel, India; $>99.5 \%$ purity), and citric acid (Loba Chemie,
India; $99.5 \%$ ) for the synthesis of powders. Aqueous solutions of metal nitrates were mixed with an aqueous solution of citric acid maintaining a constant citrate to nitrate ratio of 0.3 [42]. The mixed solution was evaporated with continuous stirring at $200 \pm 5^{\circ} \mathrm{C}$ until it gelled and finally burnt. Within a few seconds, the combustion reaction completed giving yellow porous ash filling the container. The ash was calcined at $600{ }^{\circ} \mathrm{C}$ in air for $4 \mathrm{~h}$. Calcined powder was uniaxially pressed under a load of $70 \mathrm{kN}$ into green pellets having $15 \mathrm{~mm}$ diameter. The green pellets were sintered at $1,350{ }^{\circ} \mathrm{C}$ for $4 \mathrm{~h}$ in air.

Sample characterization

Crystal structure of sintered powder was determined using a Rigaku high-resolution powder X-ray diffractometer employing
Fig. 2 Scanning electron micrographs of various compositions. a CCO5. b CC5S1. c CC5S2. d CC5S3 thermally etched at $1,250{ }^{\circ} \mathrm{C}$
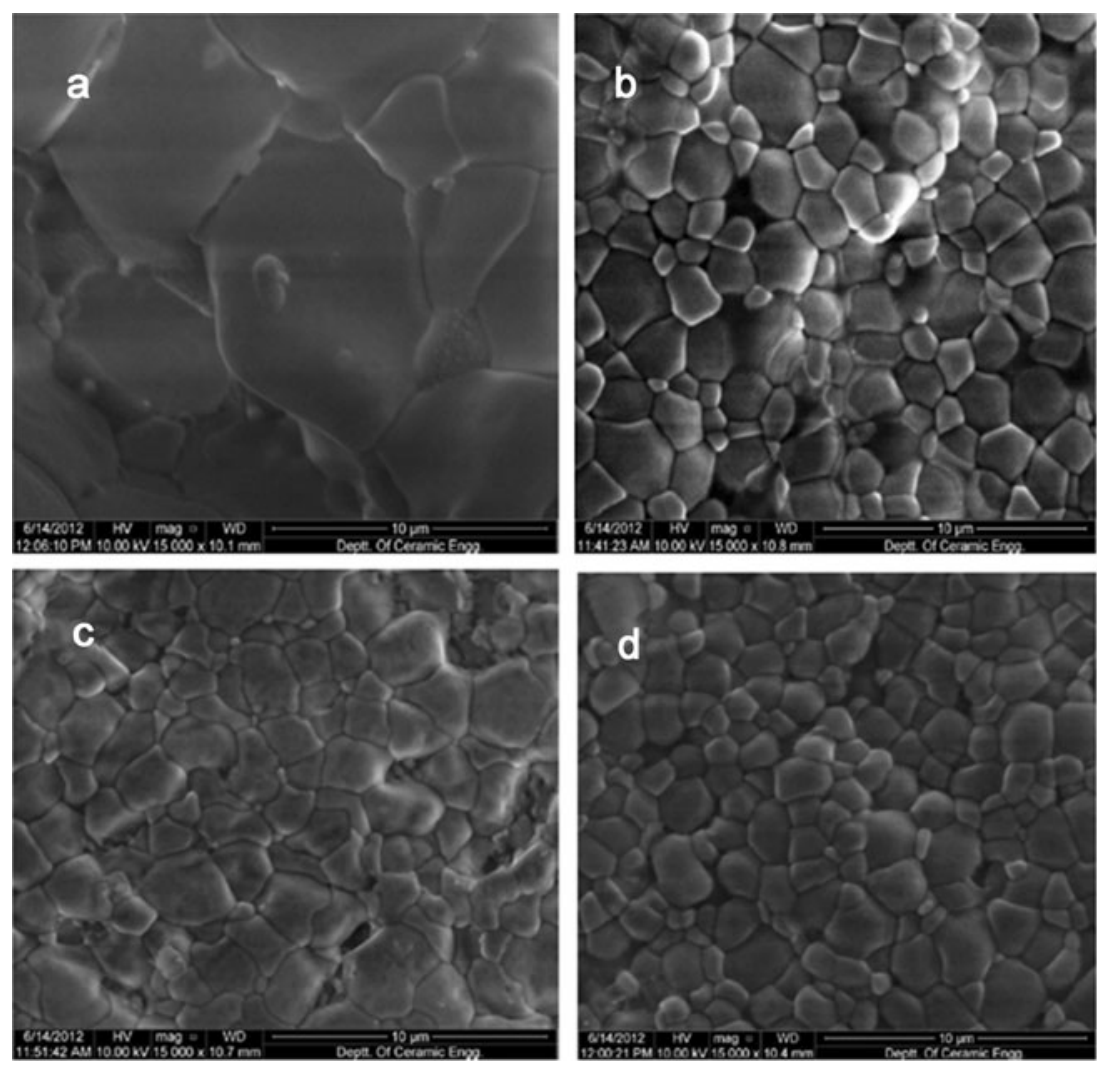
$\mathrm{Cu} \mathrm{K}_{\alpha 1}$ radiation and Ni filter. Data were collected in the Bragg angle range of $20^{\circ} \leq 2 \theta \leq 80^{\circ}$. The crystallite size, $D$ of the sintered powder, was determined using Scherrer's formula:

$D=\frac{0.9 \lambda}{\beta \cos \theta}$

where $\beta$ is the full width at half maxima excluding instrumental broadening, $\lambda$ is the wave length of $\mathrm{X}$-ray radiation, and $\theta$ is the Bragg angle. $\beta$ is taken for the strongest Bragg's peak corresponding to (111) reflection for all the samples. Lattice parameters were calculated using "Unit Cell" software [43]. Density of sintered pellets was determined by Archimedes method and expressed as percentage of theoretical density determined from the lattice parameter and molecular weight of the compound. Sintered pellets were polished using emery papers of grade $1 / 0$, $2 / 0,3 / 0$, and $4 / 0$ (Sia, Switzerland) followed by polishing on a velvet cloth using diamond paste of grade1/4-OS-475 (HIFIN). Then, these were etched thermally at $1,250{ }^{\circ} \mathrm{C}$. Micrographs were taken with the help of a scanning electron microscope (INSPECT 50 FEI').

\section{Conductivity measurement}

For conductivity measurements, $\mathrm{Ag}$ paste was applied on both surfaces of the pellet. The paint was cured at $700^{\circ} \mathrm{C}$ for $15 \mathrm{~min}$ to form silver electrodes. Conductivity was determined by impedance spectroscopy. Impedance measurements were made using a Novocontrol Alpha-A High-Performance Frequency Analyzer with an applied voltage of $20 \mathrm{mV}$ in air in the temperature and frequency range $200-600{ }^{\circ} \mathrm{C}$ and $1 \mathrm{~Hz}$ to $1 \mathrm{MHz}$, respectively. Data were collected using "Win data" program and fitted to the corresponding equivalent circuit using ZView software.

\section{Results and discussion}

\section{Crystal structure}

Figure 1 shows $\mathrm{X}$-ray diffraction patterns of the powders of sintered pellets for the system $\mathrm{Ce}_{0.95-x} \mathrm{Ca}_{0.05} \mathrm{Sr}_{x} \mathrm{O}_{1.95-x}(x=0.00$, $0.01,0.02$, and 0.03 ). Characteristic lines of constituent oxides are not observed in the diffraction patterns. All the samples are single phase having cubic fluorite structure. X-ray diffraction (XRD) patterns of the calcined powders are similar to those obtained after sintering except that the diffraction lines become sharper as shown in Fig. 1. This is due to grain growth occurring during sintering. There is a slight shift in $2 \theta$ values from the corresponding $2 \theta$ values of undoped ceria. Diffraction patterns were indexed on the basis of fluorite structure similar to $\mathrm{CeO}_{2}$ using JCPDS file no. 43-1002. Lattice parameter of all the samples is given in Table 1. Lattice parameter is found to increase with strontium content because ionic radius of $\mathrm{Sr}^{2+}$

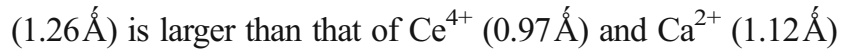
[44]. Crystallite size, $D$ of the calcined powder calculated from $\mathrm{X}$-ray line broadening using Scherrer's formula, is in the range 47-57 nm. Density of the sintered pellets of all the samples, determined by Archimedes principle, is more than $97 \%$ of the theoretical density (Table 1).

Figure 2 shows micrographs of thermally etched samples at $1,250{ }^{\circ} \mathrm{C}$. Micrographs of the surface of the sintered samples show well-defined grains separated by grain boundaries. All sintered samples have grains with varying sizes. As strontium content increases, a narrowing of grain size distribution is observed. Average grain size of the compositions with $x=0.00,0.01,0.02$, and 0.03 determined by linear intercept method is approx. $6.0,2.5,2.0$, and $1.5 \mu \mathrm{m}$, respectively. It is observed from Fig. 2 that average grain size decreases with increasing concentration of $\mathrm{Sr}$, indicating that $\mathrm{Sr}$ acts as a grain growth inhibitor. This may be due to segregation of $\mathrm{Sr}^{2+}$ at grain boundaries due to elastic strain arising out of size mismatch of $\mathrm{Sr}^{2+}$ and $\mathrm{Ce}^{4+}$. Whenever we dope a material with another ion, two types of strains are developed. Elastic strain arises due to difference between the ionic radii of the host ion and dopant ion. Electrostatic strain arises due to difference in their valency. Both these strains lead to increase in the energy of the materials. Grain boundaries are regions of high energy because of disorder present in them. Therefore, the dopant ions can be accommodated in the grain boundaries with minimum expenditure of extra energy, i.e., dopants tend to segregate to the grain boundaries. In the present materials, the excess concentration of dopants $\left(\mathrm{Sr}^{2+}\right.$ in this case) may not be enough at grain boundaries so that it appears as a different phase in XRD. This can however be studied by using EDX and electron microprobe analysis.

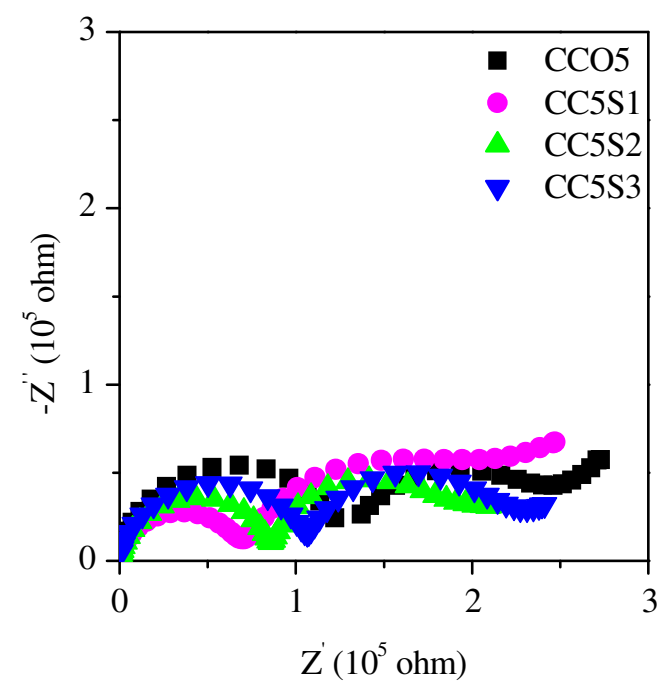

Fig. 3 Impedance plots of all the compositions in the system $\mathrm{Ce}_{0.95}$ ${ }_{-x} \mathrm{Ca}_{0.05} \mathrm{Sr}_{x} \mathrm{O}_{1.95-x}$ at $200{ }^{\circ} \mathrm{C}$ 

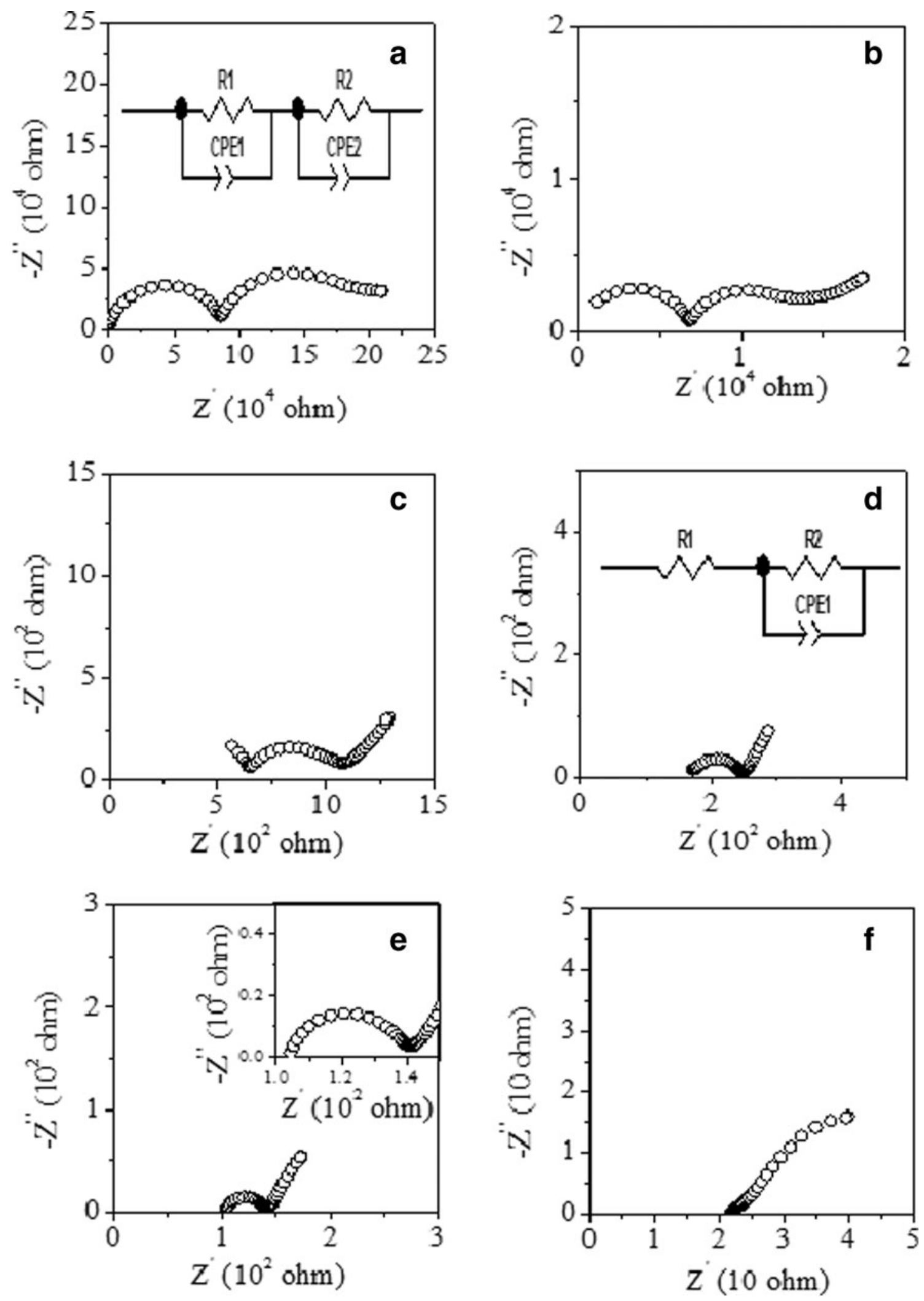

Fig. 4 Impedance plots of the composition CC5S2 at a $200{ }^{\circ} \mathrm{C}$, b $250{ }^{\circ} \mathrm{C}$, c $325^{\circ} \mathrm{C}$, d $375{ }^{\circ} \mathrm{C}$, e $425{ }^{\circ} \mathrm{C}$, and f $500{ }^{\circ} \mathrm{C}$ 


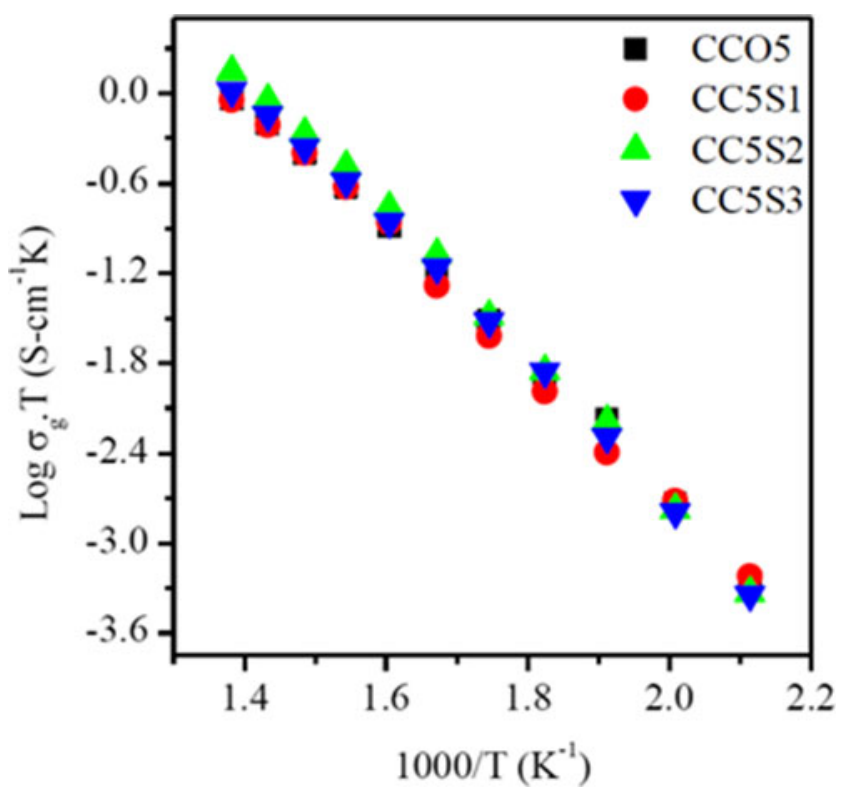

Fig. 5 Arrhenius plots for grain ionic conductivity of all the compositions in the system $\mathrm{Ce}_{0.95-x} \mathrm{Ca}_{0.05} \mathrm{Sr}_{x} \mathrm{O}_{1.95-x}$

\section{Electrical conductivity}

Conductivity of doped ceria in air has been reported to be completely ionic in nature [34]. In this paper, the conductivity measured in air can be treated as oxide ion conductivity. Electrical conductivity of the samples was studied using complex plane impedance analysis. Complex plane impedance plots at $200^{\circ} \mathrm{C}$ of all the compositions studied are shown in Fig. 3. Impedance plots of CC5S2 composition at different temperatures are plotted in Fig. 4. Typically, three arcs are observed in the complex plane impedance plots of polycrystalline materials. The arc present in the highest frequency range is attributed to intragrain behavior, one in the intermediate frequencies is attributed to grain boundaries, and the third arc in the lowest frequency range is assigned to electrode-electrolyte interface polarization. Impedance plots at $200{ }^{\circ} \mathrm{C}$ (Fig. 3) exhibit two distinct arcs corresponding to grains and grain boundaries, and a third arc corresponding to electrode-electrolyte interface starts appearing. As the temperature increases, the arcs shift to higher frequency leading to

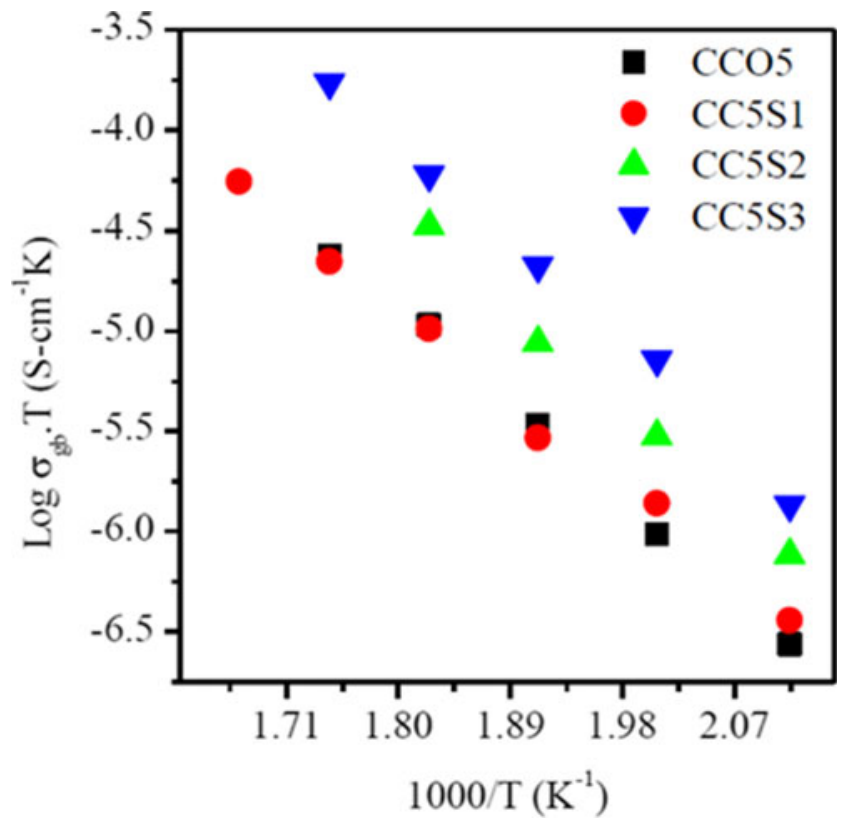

Fig. 6 Arrhenius plots for specific grain boundary conductivity of all the compositions in the system $\mathrm{Ce}_{0.95-x} \mathrm{Ca}_{0.05} \mathrm{Sr}_{x} \mathrm{O}_{1.95-x}$

disappearance of the arcs due to contributions of grains and grain boundaries. The grain arc disappeared at temperature above $325^{\circ} \mathrm{C}$, and beyond $450{ }^{\circ} \mathrm{C}$, grain boundary arc also disappeared. At higher temperatures, only electrode arc appears. All the three arcs are not clearly seen in the impedance plots at all temperatures because of limited frequency range available in the equipment. The grains and grain boundaries arcs are associated with the capacitances in the $\mathrm{pF}\left(10^{-10}\right.$ $\left.10^{-12}\right)$ and $\mathrm{nF}\left(10^{-7}-10^{-9}\right)$ ranges [45]. These are determined from the relation $2 \pi f_{\max } \mathrm{RC}=1$, where $f_{\max }$ is the applied frequency at the arc maximum, $R$ is the resistance, and $C$ is the capacitance of a particular contribution. In order to see clearly the contribution of the grain boundaries, the data is plotted on an expanded scale in the insets. Impedance spectra were fitted using the equivalent circuit containing two parallel resistance $(R)$ - constant phase element (CPE) circuits connected in series one for the bulk and other for the grain boundaries. In the present analysis, a CPE [46] is used for fitting the data instead of a capacitor (Fig. 4). The CPE accounts for the microstructure inhomogeneity within the sample, and it is equivalent to a

Table 2 Total conductivity at $600{ }^{\circ} \mathrm{C}\left(\sigma_{\mathrm{t}}\right)$, activation energy of grains $\left(E_{\mathrm{g}}\right)$, grain boundaries $\left(E_{\mathrm{gb}}\right)$, total $\left(E_{\mathrm{t}}\right)$ conductivity, and thickness of the grain boundary $\left(\delta_{\mathrm{gb}}\right)$ of various compositions in the system $\mathrm{Ce}_{0.95-x} \mathrm{Ca}_{0.05} \mathrm{Sr}_{x} \mathrm{O}_{1.95-x}$

\begin{tabular}{lllllll}
\hline S. no. & Compositions & $\delta_{\text {gb }}(\mathrm{nm})$ & $\sigma_{\mathrm{t}}$ at $600{ }^{\circ} \mathrm{C}\left(\mathrm{S} \mathrm{cm}^{-1}\right)$ & $E_{\mathrm{g}}(\mathrm{eV})\left(200-450{ }^{\circ} \mathrm{C}\right)$ & $E_{\mathrm{gb}}(\mathrm{eV})\left(200-450{ }^{\circ} \mathrm{C}\right)$ & $E_{\mathrm{t}}(\mathrm{eV})\left(200-600{ }^{\circ} \mathrm{C}\right)$ \\
\hline 1. & $\mathrm{Ce}_{0.95} \mathrm{Ca}_{0.05} \mathrm{O}_{1.95}$ & 5.42 & $7.98 \times 10^{-3}$ & $0.88 \pm 0.08$ & $1.06 \pm 0.12$ & $0.93 \pm 0.06$ \\
2. & $\mathrm{Ce}_{0.94} \mathrm{Ca}_{0.05} \mathrm{Sr}_{0.01} \mathrm{O}_{1.94}$ & 3.78 & $1.04 \times 10^{-2}$ & $0.89 \pm 0.07$ & $0.97 \pm 0.15$ & $0.99 \pm 0.05$ \\
3. & $\mathrm{Ce}_{0.93} \mathrm{Ca}_{0.05} \mathrm{Sr}_{0.02} \mathrm{O}_{1.93}$ & 4.66 & $1.66 \times 10^{-2}$ & $0.94 \pm 0.08$ & $1.10 \pm 0.23$ & $0.97 \pm 0.05$ \\
4. & $\mathrm{Ce}_{0.92} \mathrm{Ca}_{0.05} \mathrm{Sr}_{0.03} \mathrm{O}_{1.92}$ & 4.56 & $1.22 \times 10^{-2}$ & $0.92 \pm 0.07$ & $1.11 \pm 0.19$ & $0.95 \pm 0.04$ \\
\hline
\end{tabular}


distribution of capacitors in parallel. In Fig. $4, R_{1}, R_{2}$, CPE1, and CPE2 stand for grain resistance, grain boundary resistance, $\mathrm{CPE}$ of grains, and CPE of grain boundaries, respectively. The contribution of the electrode-specimen interface (which is given by the third arc) is not considered here because total resistance of electrolyte is given by the sum of grain $\left(R_{\mathrm{g}}\right)$ and grain boundary resistance $\left(R_{\mathrm{gb}}\right)$. These circuits are used to obtain the best fit and adequately determine the electrolyte resistance.

Total resistance of the sample is given by $R_{\mathrm{t}}=R_{\mathrm{g}}+R_{\mathrm{gb}}$. Resistance of grains $\left(R_{\mathrm{g}}\right)$ and grain boundaries $\left(R_{\mathrm{gb}}\right)$ can be determined by fitting the impedance data. Total conductivity $\left(\sigma_{t}\right)$ has been determined using the formula:

$\sigma_{\mathrm{t}}=\frac{1}{R} \times \frac{L}{S}$

where $L$ is the thickness and $S$ is the area of the sample.

An important feature of ceria is its tolerance to doping due to its relatively open structure. Addition of divalent cations in ceria produces oxygen vacancies responsible for ionic conduction $[47,48]$ as given below in the Eqs. 3 and 4:

$\mathrm{SrO} \stackrel{\mathrm{CeO}_{2}}{\rightarrow} \mathrm{Sr}^{\prime \prime} \mathrm{Ce}+O_{\mathrm{o}}+V_{\mathrm{o}}^{\cdot \bullet}$

$\mathrm{CaO} \stackrel{\mathrm{CeO}_{2}}{\longrightarrow} \mathrm{Ca}^{\prime \prime} \mathrm{Ce}+O_{\mathrm{o}}+V_{\mathrm{o}}^{. \cdot}$

Arrhenius plots of bulk conductivities for all the samples in the temperature range $200-450{ }^{\circ} \mathrm{C}$ are shown in Fig. 5 . It can be seen from Fig. 5 that the value of bulk conductivity is highest for the sample $\mathrm{Ce}_{0.93} \mathrm{Ca}_{0.05} \mathrm{Sr}_{0.02} \mathrm{O}_{1.93}$ and starts decreasing beyond $x(\mathrm{Sr})=0.02$. Value of grain ionic conductivity for the sample $\mathrm{Ce}_{0.93} \mathrm{Ca}_{0.05} \mathrm{Sr}_{0.02} \mathrm{O}_{1.93}$ is $1.39 \times 10^{-4} \mathrm{~S} \mathrm{~cm}^{-1}$ at $325^{\circ} \mathrm{C}$, which is much higher than the value $6.0 \times 10^{-6} \mathrm{~S} \mathrm{~cm}^{-1}$ reported by Junior et al. [49] for the sample $\mathrm{Ce}_{0.90} \mathrm{Ca}_{0.05} \mathrm{Sr}_{0.05} \mathrm{O}_{1.90}$ at $320^{\circ} \mathrm{C}$. These plots are linear having a single slope. Activation energy of conduction $\left(E_{\mathrm{g}}\right)$ has been determined using Arrhenius relationship:

$\sigma_{\mathrm{g}}=\frac{\sigma_{0 \mathrm{~g}}}{T} \cdot \exp \left(\frac{-E_{\mathrm{g}}}{k T}\right)$

where $\sigma_{0 \mathrm{~g}}$ is the pre-exponential factor, $k$ is the Boltzmann constant, and $T$ is the absolute temperature. Values of activation energy of bulk ionic conductivity $\left(E_{\mathrm{g}}\right)$ for all the samples determined from the plots by least square fitting of the data points in Fig. 5 are given in Table 2.

According to Verkerk [50] and Christie et al. [46], there exists a relation between apparent grain boundaries conductivity $\left(\sigma_{\mathrm{gb}}\right)$ determined from the grain boundary arc of impedance plot and specific grain boundaries conductivity $\sigma_{\mathrm{gb}}{ }^{*}$ as given by Eq. 6:

$\sigma_{\mathrm{gb}}^{*}=\left(\frac{\delta_{\mathrm{gb}}}{d_{\mathrm{g}}}\right) \sigma_{\mathrm{gb}}$

where $\delta_{\mathrm{gb}}$ is the thickness of the grain boundary and $d_{\mathrm{g}}$ is the average grain size. If bulk and grain boundary permittivities are similar, then Eq. 6 can be written as:

$\sigma_{\mathrm{gb}}^{*}=\frac{C_{\mathrm{g}}}{C_{\mathrm{gb}}} \sigma_{\mathrm{gb}}$

where $C_{\mathrm{g}}$ and $C_{\mathrm{gb}}$ are bulk and grain boundary capacitance determined from the impedance plots.

Arrhenius plots for specific grain boundary conductivity are shown in Fig. 6. Thickness of grain boundary can be calculated from Eqs. 6 and 7, and it is in the range of 2-5 nm (given in Table 2) in agreement with the values reported by Guo et al. [51].

It is seen from Fig. 6 that the grain boundary conductivity depends on Sr content, and it is higher for co-doped samples. This may be due to two factors. One is due to scavenging effect of Sr. Grain boundary blocking factor $\left(\alpha_{g b}\right)$ has been used to confirm the scavenging effect of $\mathrm{Sr}[50,52]$. It is defined as:

$\alpha_{\mathrm{gb}}=\frac{R_{\mathrm{gb}}}{R_{\mathrm{g}}+R_{\mathrm{gb}}}$.

Blocking factor $\alpha_{\mathrm{gb}}$ gives the fraction of charge carriers being blocked at the impermeable internal surface, under the

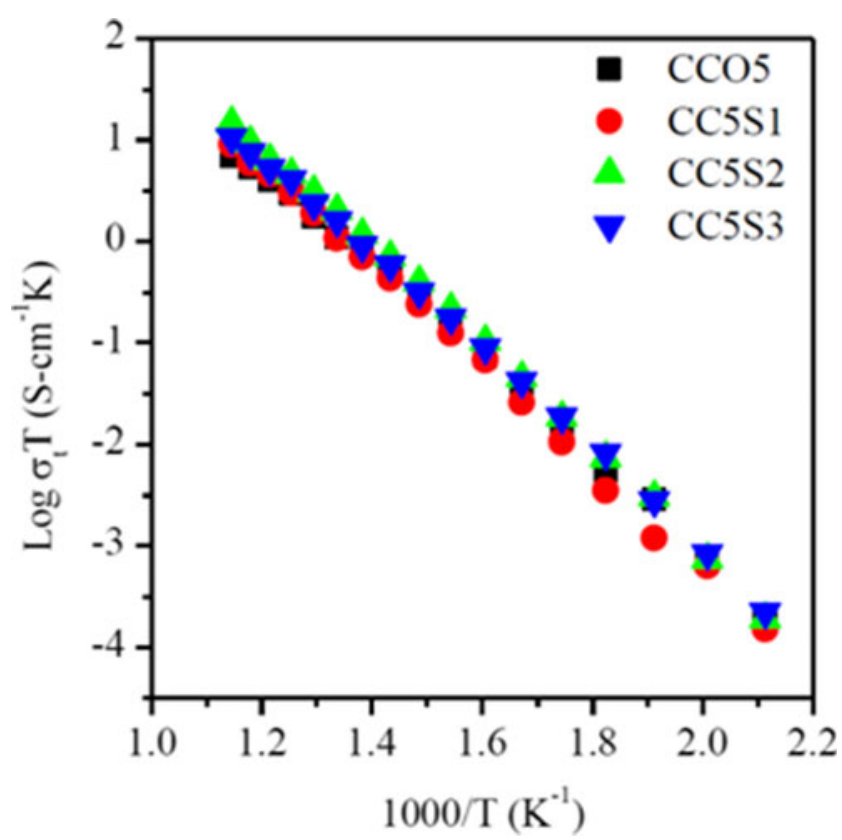

Fig. 7 Arrhenius plots for total ionic conductivity of all the compositions in the system $\mathrm{Ce}_{0.95-x} \mathrm{Ca}_{0.05} \mathrm{Sr}_{x} \mathrm{O}_{1.95-x}$ 
measuring conditions, with respect to the total number of charge carriers in the samples. Value of $\alpha_{\mathrm{gb}}$ is 0.37 for the sample $\mathrm{Ce}_{0.95} \mathrm{Ca}_{0.05} \mathrm{O}_{1.95}$ which is maximum and 0.11 for $\mathrm{Ce}_{0.93} \mathrm{Ca}_{0.05} \mathrm{Sr}_{0.02} \mathrm{O}_{1.93}$ at $400{ }^{\circ} \mathrm{C}$ being minimum of all the samples. This may be due to scavenging effect of $\mathrm{Sr}^{2+}$ ions to remove siliceous impurities. It has been reported by Gerhardt et al. [52] that grain boundary effect depends on dopant concentration and dopant size. The grain boundary resistivity decreases sharply with increasing concentration and size of the dopants. Concentration and nature of the dopants control how much Si goes into solid solution and how much is segregated. On the basis of scanning transmission electron microscopy combined with energy dispersive X-ray microanalysis and electron energy loss spectroscopy, Gerhardt et al. [53] reported that in yttrium-doped ceria, there exists an amorphous silica thick layer surrounding the grains. This layer blocks the charge carriers leading to increase in the resistivity of the grain boundaries. They also observed the formation of some silicate phases of yttrium. The amount of these phases increases as the yttrium concentration increases. These phases pocket at the triple point junction, leaving clean grain to grain contacts area. Therefore, the amount of $\mathrm{Si}$ decreases as the concentration of dopants increases, i.e., less amount of $\mathrm{Si}$ is available for the formation of thick boundary layer. Similar silicate phases may form in the materials under present investigation. The exact compositions, morphology, and distribution of these phases require analytical studies as mentioned above. Removal of silica decreases the resistivity of the grain boundaries leading to decrease in the total resistivity. In the present investigation, an optimum value of $\mathrm{Sr}$ for scavenging effect is $2 \mathrm{~mol} \%$. Beyond this concentration, elastic strain seems to dominate leading to decrease in the conductivity.

Second is the decrease in the average grain size. It can be observed from Fig. 6 that specific grain boundary conductivity increases with decreasing grain size. Small grain size samples exhibit much higher grain boundary conductivity. This is because of the large grain boundary area for which the finite amount of impurity contained in these samples is not sufficient to form a continuous and uniform glassy phase layer along grain boundaries. This leaves the remaining grain boundary area for clean grain to grain contact [54]. Therefore, the transport of $\mathrm{O}^{2-}$ ions becomes faster across the grains through clean grain boundaries.

Values of activation energy of grain boundary conduction $\left(E_{\mathrm{gb}}\right)$ are given in Table 2 . These values of $E_{\mathrm{gb}}$ are consistently higher than the corresponding $E_{\mathrm{g}}$ values.

Plots of $\log \sigma_{\mathrm{t}} T$ vs. 1,000/T for all the compositions are shown in Fig. 7. These plots are linear with a single slope. Values of activation energy of total conductivity determined from the slope of these plots are given in Table 2.

Values of $\sigma_{\mathrm{t}}$ at $600{ }^{\circ} \mathrm{C}$ for different compositions are given in Table 2. Values of $\sigma_{\mathrm{t}}$ increase with increasing $\mathrm{Sr}$ content up to $2 \mathrm{~mol} \%$. In the present study, an addition of $\mathrm{Ca}$ and $\mathrm{Sr}$ to ceria leads to some opposite competing effects. First is the ordering of oxygen vacancies is suppressed due to co-doping reported by Yamamura et al. [55]. This decreases the activation energy for migration of $\mathrm{O}^{2-}$ ion, consequently increasing the conductivity. Second is due to scavenging effect of grain boundaries by $\mathrm{Sr}^{2+}$ leading to increase in the grain boundaries as well as total conductivity. Third is that the ionic size

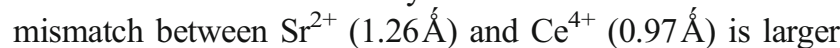
than that between $\mathrm{Ca}^{2+}(1.12 \AA \hat{)})$ and $\mathrm{Ce}^{4+}(0.97 \AA \hat{)})$ [56]. The elastic strain therefore increases with increasing $x(\mathrm{Sr})$. This decreases the conductivity because of an increase in activation energy for diffusion of $\mathrm{O}^{2-}$ ion. Concentration of oxygen vacancies also increases with increasing $x$. At the same time, the probability of the formation of associated defect pairs $\left(\mathrm{Ca}_{\mathrm{Ce}}{ }^{\prime \prime}-\mathscr{b}^{\bullet}\right.$ or $\left.\mathrm{Sr}_{\mathrm{Ce}}{ }^{\prime \prime}-\mathscr{G}^{\bullet}\right)$ also increases with increasing $x$. Because of the complex interplay of these opposite competing effects, conductivity increases up to $x=0.02$ and decreases thereafter.

Composition, $\mathrm{Ce}_{0.93} \mathrm{Ca}_{0.05} \mathrm{Sr}_{0.02} \mathrm{O}_{1.93}$ shows the highest conductivity among all the compositions studied. Its conductivity at $600{ }^{\circ} \mathrm{C}\left(1.66 \times 10^{-2} \mathrm{~S} \mathrm{~cm}^{-1}\right)$ is higher than the reported values of conductivity for the compositions $\mathrm{Ce}_{0.80} \mathrm{Sm}_{0.20} \mathrm{O}_{1.90}\left(1.20 \times 10^{-2} \mathrm{~S} \mathrm{~cm}^{-1}\right)$ [57] and $\mathrm{Ce}_{0.80} \mathrm{Gd}_{0.20} \mathrm{O}_{1.90}\left(1.29 \times 10^{-2} \mathrm{~S} \mathrm{~cm}^{-1}\right)$ [58] at $600{ }^{\circ} \mathrm{C}$. Conductivity of composition for $\mathrm{Ce}_{0.93} \mathrm{Ca}_{0.05} \mathrm{Sr}_{0.02} \mathrm{O}_{1.93}$ is also higher than the maximum value reported for singly $\mathrm{Sr}$-doped ceria $\mathrm{Ce}_{0.95} \mathrm{Sr}_{0.05} \mathrm{O}_{1.95}\left(1.53 \times 10^{-2} \mathrm{~S} \mathrm{~cm}^{-1}\right)$ at $600^{\circ} \mathrm{C}$ [59]. It is concluded that the composition $\mathrm{Ce}_{0.93} \mathrm{Ca}_{0.05} \mathrm{Sr}_{0.02} \mathrm{O}_{1.93}$ has more conductivity than that of ceria singly or co-doped with rare earth ions such as $\mathrm{Sm}^{3+}$ and $\mathrm{Gd}^{3+}$. Use of this material as a solid electrolyte for IT-SOFC is expected to reduce the cost drastically. Measurement of thermal expansion coefficient as a function of temperature and long-term stability needs to be studied for its application in IT-SOFCs.

\section{Conclusions}

Samples in the system, $\mathrm{Ce}_{0.95-x} \mathrm{Ca}_{0.05} \mathrm{Sr}_{x} \mathrm{O}_{1.95-x}(x=0.00,0.01$, 0.02 , and 0.03 ), have been prepared by citrate-nitrate route. Single-phase solid solution forms in all the compositions at low temperature as $600{ }^{\circ} \mathrm{C}$. Density of all the compositions is more than $97 \%$ of the theoretical value. Conductivity of compositions increases with an increase in $\mathrm{Sr}$ concentration up to $2 \mathrm{~mol} \%$ and then it decreases. Composition with $x=0.02$ exhibits the maximum ionic conductivity. This is higher than the maximum values reported in SDC and GDC. This may make this material suitable as a solid electrolyte for IT-SOFCs application.

Acknowledgment Thanks are due to the Department of Science and Technology, New Delhi for financial support. 
Open Access This article is distributed under the terms of the Creative Commons Attribution License which permits any use, distribution, and reproduction in any medium, provided the original author(s) and the source are credited.

\section{References}

1. Arai H (1992) Oxygen ion conductor and its application. J Bull Ceram Soc Jpn 27:100-104

2. Miura N, Kurosawa H, Hasei M, Lu G, Yamazoe N (1996) Stabilized zirconia-based sensor using oxide electrode for detection of NOx in hightemperature combustion-exhausts. Solid State Ionics 86-88:1069-1073

3. Yamazoeand N, Miura N (1996) Prospect and problems of solid electrolyte-based oxygenic gas sensors. Solid State Ionics 8688:987-993

4. Minh NQ (1993) Ceramic fuel cells. J Am Ceram Soc 76:563-588

5. Hibino T, Iwahara H (1994) Improvement of CAPCIUS cell using $\mathrm{SrCe}_{0.95} \mathrm{Yb}_{0.05} \mathrm{O}_{3-\alpha}$ as a solid electrolyte. Chem Lett 35:485-488

6. Sasaki H, Otoshi S, Suzuki M, Sogi T, Kajimura A, Sagiura N, Ippommatsu M (1994) Fabrication of high power density tabular type solid oxide fuel cells. Solid State Ionics 72:253-256

7. Inaba H, Tagawa H (1996) Ceria based solid electrolytes. Solid State Ionics 83:1-16

8. Stefanik ST, Tuller LH (2001) Ceria-based gas sensors. J Eur Ceram Soc 21:1967-1970

9. Jurado JR (2001) Present several items on ceria-based ceramic electrolytes: synthesis, additive effects, reactivity and electrochemical behavior. J Mater Sci 36:1133-1139

10. Kharton VV, Figueiredo FM, Navarro L, Naumovich EN, Kovalevsky AV, Yaremchenko AA, Viskup AP, Carneiro A, Marques FMB, Frade JR (2001) Ceria based materials for solid oxide fuel cells. J Mater Sci 36:1105-1117

11. Doshi R, Richards VL, Carter JD, Wang X, Krumpelt M (1999) Development of solid oxide fuel cells that operate at $500^{\circ} \mathrm{C}$. J Electrochem Soc 146:1273-1278

12. Godickemeier M, Gauckler LJ (1998) Engineering of solid oxide fuel cells with ceria-based electrolytes. J Electrochem Soc 145:414-421

13. Zhu B, Liu X, Sun M, Ji Sun S (2003) Calcium doped ceria-based materials for cost-effective intermediate temperature solid oxide fuel cells. J Solid State Sci 5:1127-1134

14. Bellon O, Sammes NM, Staniforth J (1998) Mechanical properties and electrochemical characterisation of extruded doped cerium oxide for use as an electrolyte for solid oxide fuel cells. J Power Sources 75:116-121

15. Wang S, Kobayashi T, Dokiya M, Hashimoto T (2000) Electrical and ionic conductivity of Gd-doped ceria. J Electrochem Soc 147:3606-3609

16. Wang Y, Mori T, Li JG, Yajima Y (2003) Low-temperature fabrication and electrical property of $10 \mathrm{~mol} \% \mathrm{Sm}_{2} \mathrm{O}_{3}$-doped $\mathrm{CeO}_{2}$ ceramics. Sci Technol Adv Mater 4:229-238

17. Kim DJ (1989) Ionic conductivities, and solubility limits in fluoritestructure $\mathrm{MO}_{2}$ oxide $\left[M=\mathrm{Hf}^{4+}, \mathrm{Zr}^{4+}, \mathrm{Ce}^{4+}, \mathrm{Th}^{4+}, \mathrm{U}^{4+}\right]$ solid solutions. J Am Ceram Soc 72:1415-1421

18. Yahiro H, Ohuchi T, Eguchi K, Arai H (1988) Electrical properties and microstructure in the system ceria-alkaline earth oxide. J Mater Sci 23:1036-1041

19. Sameshima S, Ichikawa T, Kawaminami M, Hirata Y (1999) Thermal and mechanical properties of rare earth-doped ceria ceramics. Mater Chem Phys 61:31-35

20. Blumenthal RN, Pinz BA (1967) Nature of the electrical conduction transients observed in $\mathrm{CeO}_{2}$ and $\mathrm{Ca}$-doped $\mathrm{CeO}_{2}$. J Appl Phys $38: 2376-2378$
21. Arai H, Kunisaki T, Shimizu Y, Seiyama T (1986) Electrical properties of calcia-doped ceria with oxygen ion conduction. Solid State Ionics 20:241-248

22. Blumenthal RN, Garnier JE (1976) The electrical conductivity and thermodynamic behavior of SrO-doped nonstoichiometric cerium dioxide. J Solid State Chem 16:21-34

23. Yahiro H, Eguchi K, Arai $\mathrm{H}$ (1986) AC conductivity and conductivity relaxation studies in the $\mathrm{CeO}_{2}-\mathrm{Y}_{2} \mathrm{O}_{3}$ system. Solid State Ionics 21:49-53

24. Ong Poh Shing, Tan Yen Ping, and Taufiq Yap Yun Hin (2011) Mechanochemical synthesis and characterization of calcium doped ceria oxide ion conductor Material Science and Engineering 17: doi:10.1088/1757-899X/17/1/012017

25. Yamashita K, Ramanujachary KV, Greenblatt M (1995) Hydrothermal synthesis and low temperature conduction properties of substituted ceria ceramics. Solid State Ionics 81:53-60

26. Banerjee S, Devi PS (2008) Understanding the effect of calcium on the properties of ceria prepared by a mixed fuel process. Solid State Ionics 179:661-669

27. Holtappels P, Poulsen FW, Mogensen M (2000) Electrical conductivities and chemical stabilities of mixed conducting pyrochlores for SOFC applications. Solid State Ionics 135:675-679

28. Tuller HL, Tuller H, Schoonman J, Riess I (2000) Oxygen ion and mixed conductors and their technological applications. In: Riess I (ed) Defects and transport. Kluwer (NATO ASI series), Dordrecht, pp 245-270

29. Etsell H, Flengas SN (1970) The electrical properties of solid oxide electrolytes. Chem Rev 70:339-376

30. Rickert H (1982) Electrochemistry of solids - an introduction. Springer-Verlag, Berlin

31. Chebotin VN, Perfilyev MV (1978) Electrochemistry of solid electrolytes. Khimiya, Moscow

32. Perfilyev MV, Demin AK, Kuzin BL, Lipilin AS (1988) High temperature electrolysis of gases. Nauka, Moscow

33. Kharton VV, Naumovich EN, Vecher AA (1999) Research on the electrochemistry of oxygen ion conductors in the former Soviet Union I $\mathrm{ZrO}_{2}$-based ceramic materials. J Solid State Electrochem 3:61-81

34. Inaba H, Tagawa H (1996) Ceria based electrolytes. Solid State Ionics 83:1-16

35. Bouwmeester HJM, Burggraaf AJ (1996) In: Burggraaf A, Cot L (eds) Fundamentals of inorganic membrane science and technology. Elsevier, Amsterdam, pp 435-528

36. Sammes NM, Tompsett GA, Nafe H, Aldinger F (1999) Bismuth based oxide electrolytes - structure and ionic conductivity. J Eur Ceram Soc 19:1801-1826

37. Mogensen M, Sammes NM, Tompsett GA (2000) Physical chemical and electrochemical properties of pure and doped ceria. Solid State Ionics 129:63-94

38. Yeh T-H, Chou C-C (2007) Ionic conductivity investigation in samarium and strontium co-doped ceria system. Phys Scr 129:303-307

39. Cioatera N, Parvulescu V, Rolle A, Vannier RN (2009) Effect of strontium addition on europium-doped ceria properties. Solid State Ionics 180:681-687

40. Zheng Y, Liqiang W et al (2009) The effect of Sr on the properties of Ydoped ceria electrolyte for IT-SOFCs. J Alloys Compd 486:586-589

41. Ramesh S, Vishnuvardhan Reddy C (2009) Electrical properties of co-doped ceria electrolyte $\mathrm{Ce}_{0.8-x} \mathrm{Gd}_{0.20} \mathrm{Sr}_{x} \mathrm{O}_{2-\delta}(0.0<x<0.1)$. Acta Phys Polon A 115:909-912

42. Basu S, Sujata Devi P, Maiti HS (2004) Synthesis and properties of nanocrystalline ceria powders. J Mater Res 19:3162-3171

43. Holland TJB, Redfern SAT (1997) Unit cell refinement from powder diffraction data: the use of regression diagnostics. Mineral Mag 61:65-77

44. Shannon RD (1976) Revised effective ionic radii and systematic studies of interatomic distances in halides and chalcogenides. Acta Crystallogr A 32:751-761

45. Hodge IM, Ingram MD, West AR (1976) Impedance and modulus spectroscopy of polycrystalline solid electrolytes. J Electro Anal Chem 74:125-143 
46. Christie GM, Berkel FPF (1996) Microstructure-ionic conductivity relationships in ceria-gadolinia electrolytes. Solid State Ionics $83: 17-27$

47. Ruiz-Trejo E, Benitez-Rico A, Gomez-Reynoso S, Angeles-Rosas $\mathrm{M}$ (2007) Nanoparticles and nano-grain sized Y-doped $\mathrm{CeO}_{2}$ ceramics. J Electrochem Soc 154:A258-A262

48. Wang DY, Norwick AS (1981) Dielectric relaxation from a network of charged defects in dilute $\mathrm{CeO}_{2}: \mathrm{Y}_{2} \mathrm{O}_{3}$ solid solutions. Solid State Ionics 5:551-555

49. Junior JMS et al (2012) Raman and Rietveld structure characterization of sintered alkaline earth doped ceria. Mater Chem Phys 135:957-964

50. Verkerk MJ, Middelhuis BJ, Burggraaf AJ (1982) Effect of grain boundaries on the conductivity of high-purity $\mathrm{ZrO}_{2}-\mathrm{Y}_{2} \mathrm{O}_{3}$ ceramics. Solid State Ionics 6:159-170

51. Guo X, Waser R (2006) Electrical properties of the grain boundaries of oxygen ion conductors: acceptor doped zirconia and ceria. Prog Mater Sci 51:151-210

52. Gerhardt R, Nowick AS (1986) The grain boundary conductivity effect in ceria doped with trivalent cations. Part-I electrical behavior. J Am Ceram Soc 69:641-646
53. Gerhardt R, Nowick AS, Mochel ME, Dumler I (1986) Grain boundary effect in ceria doped with trivalent cations: II microstructure and microanalysis. J Am Ceram Soc 69:647-651

54. Tian C, Chan SW (2000) Ionic conductivities, sintering temperatures and microstructures of bulk ceramics $\mathrm{CeO}_{2}$ doped with $\mathrm{Y}_{2} \mathrm{O}_{3}$. Solid State Ionics 134:89-102

55. Yamamura $H$, Katoh E, Ichikawa M, Kakinuma K, Mori T, Haneda $H$ (2000) Multiple doping effect on the electrical conductivity in the $\left(\mathrm{Ce}_{1-}\right.$ $\left.x-y a_{x} M_{y}\right) O_{2-\delta}(M=C a, S r)$ system. Electrochemistry 68:455-459

56. Kim DK, Cho PS, Lee JH, Kim DY, Park HM, Auchterlonie G et al (2007) Mitigation of highly resistive grain-boundary phase in gadolinia-doped ceria by the addition of SrO. Electrochem Solid State Lett 10:B91-B95

57. Bryan Balazas G, Robert Glass S (1995) AC impedance studies of rare earth oxide doped ceria. Solid State Ionics 76:155-162

58. Fu Y-P, Chen S-H, Huang J-J (2010) Preparation and characterization of $\mathrm{Ce}_{0.8} \mathrm{M}_{0.2} \mathrm{O}_{2-\delta}(\mathrm{M}=\mathrm{Y}, \mathrm{Gd}, \mathrm{Sm}, \mathrm{Nd}$, La) solid electrolyte materials for solid oxide fuel cells. Int J Hydrogen Energy 35:745-752

59. Jaiswal N, Singh NK, Kumar D, Parkash O (2012) Effect of strontium (Sr) doping on the conductivity of ceria. J Power Sources 202:78-84 